\title{
真空治金（Vacuum Metallurgy）
}

秉芝マツダ研村松宏司

真空冶金とは治金技街に对して真空技行を高度に道用したものて

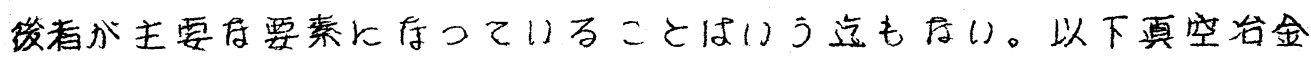

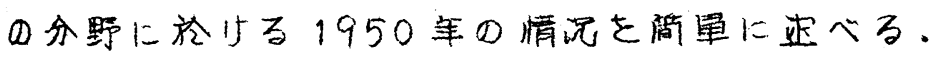

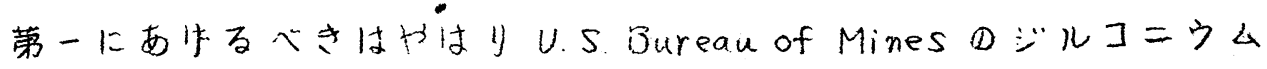
金属の武姶的装篮 ${ }^{[1<2\}}$ 及で Westinghouse のチタンをヘースとする合 金の研究 ${ }^{(3)}$ であう。ジルコニウム，49ン共に融解卓高く、しか

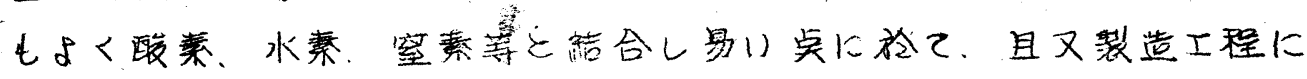

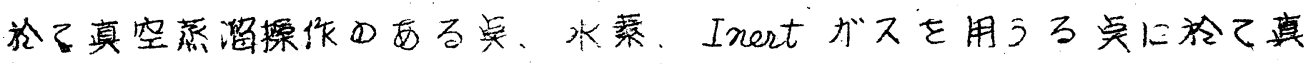

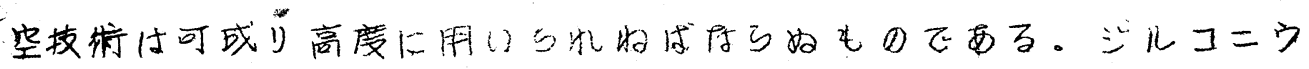

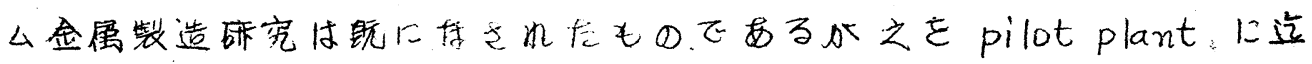
特つて行つにことは進少でる。

このPlantは一週间に300ポンドのジルコニウムスポンヂを作れ

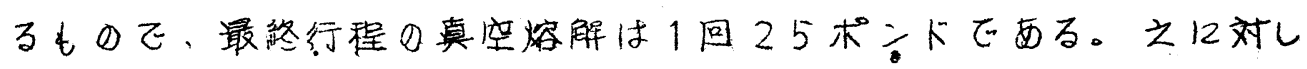

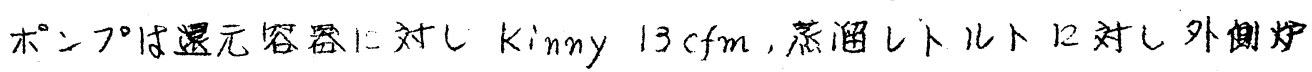

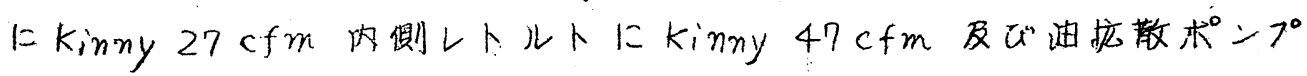
D P i 6 时 $500 \mathrm{e} / \mathrm{sec}$ at $10^{-3} \sim 10^{-4} \mathrm{mmHg}$ ह使用，熔解犵に就して时

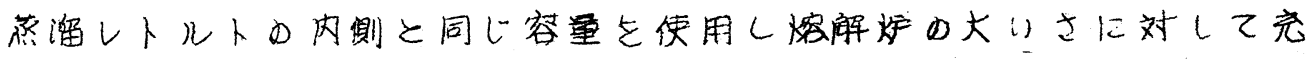

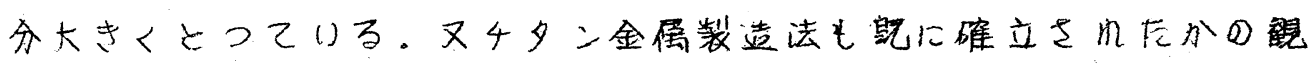

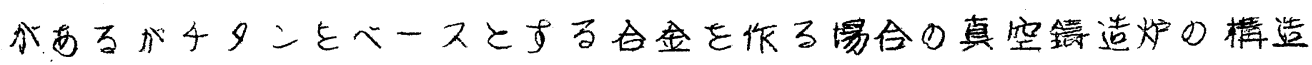
と用うる坩倜に特徽があり、特に炉の楧造が造耺軸より排気し、イ

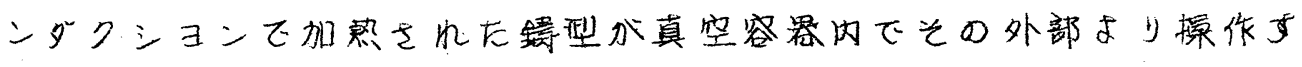

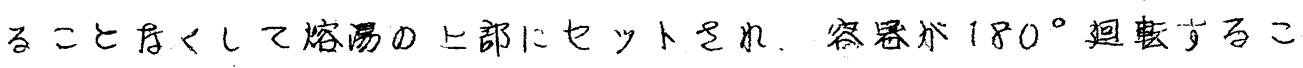

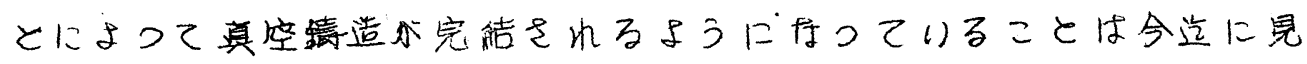

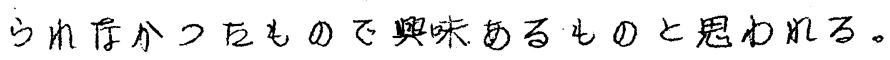

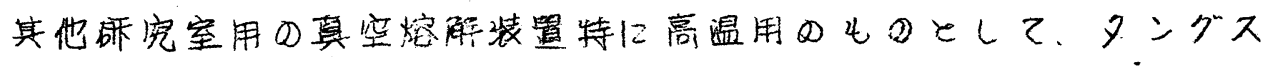
テンを抵抗体とするものて $10^{-4} \sim 10^{-5} \mathrm{mmHg}$ にて $2500^{\circ} \mathrm{C}$ 迄上げる

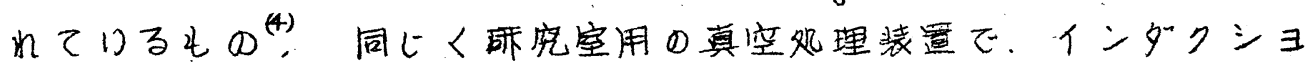




\section{(14)}

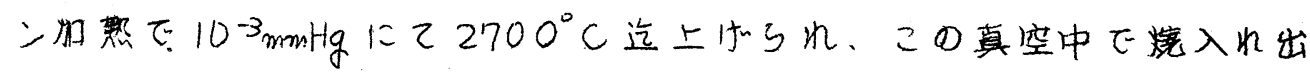
来るようにしたもの接とは应究空用装置として参考に存るものを多 く提洪している。特に後看は境入油にシリコ一ン油を用い、Vycor 管め外侧を Micarta tube と桷する絶程管を Water jacket として

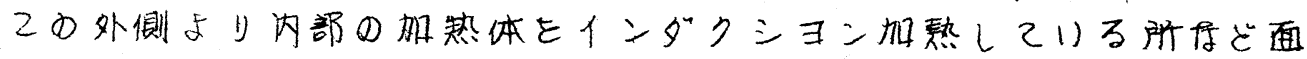
白证。

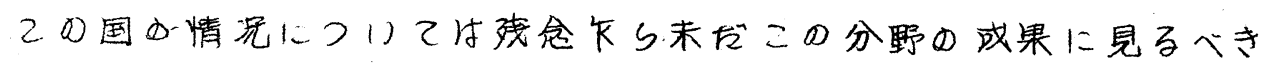
ものがはい。

交献

(1) Kroll. W. J. and Stephans. W.W.: Ind. Eng. Chem., Vol. 42, 395 (1950) Productions of Malleable Zirconium.

(2) Kroll. W. J., Stephans, W.W: and Holms, H. D., : J. Metals, P. 1445 (1950) Malleable Zirconium Production.

(3) Brace, P. H., Hurford, W. J., and Gray, T.H.; Ind. Eng. Chem., Vol. 42, P.227 (1950) Preparation and Properties of. Titanium-Base Alloys. .

(4) Alherman, K. B.: J. Sci. Inst, Vol.27, P. 280 (1950) A Small High-Temperature High-Vacuum Furnace. (5) Schramm, C.H., Gordon. P. and Kaulfmann, A.R.; J. Metals Vol 188, P.195(1950) The Alloy Systems. Uranium - Tungsten. Unanium-Tantalum and Tungsten-Tantalum. 